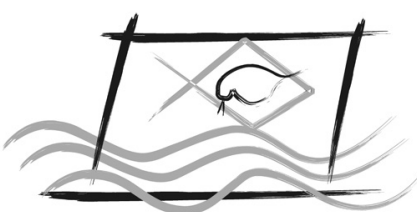

ECOTOX - BRASIL

\title{
Assessment of heavy metal contamination in sub-tropical riverine sediments using geoaccumulation index
}

\author{
Silva, P.P. ${ }^{1} ;$ SAntos, L.T.S.O. ${ }^{2} \&$ Jesus, T.B. $^{2}$ \\ 1. Departamento de Ciências Biológicas, Universidade Estadual de Feira de Santana, Avenida Transnordestina, s/n, CEP: 44036-900, \\ Feira de Santana- BA, Brasil. \\ 2. Programa de Pós-Graduação em Modelagem em Ciências da Terra e do Ambiente, Departamento de Ciências Exatas, Universidade \\ Estadual de Feira de Santana, Avenida Transnordestina, s/n, CEP: 44036-900, Feira de Santana- BA, Brasil.
}

(Received September 09, 2014; Accept December 22, 2016)

\begin{abstract}
Heavy metal determination in surface sediment allows pollutant assessment when the detection in the water column is not possible. Geoaccumulation Index (Igeo) and the Sediment Quality Guidelines (SQGs) were used to quantitatively evaluate the degree of heavy metal contamination in fluvial sediments. Both of these methods had already been used by several authors and the generated indexes allowed a good comparison parameter. In the present study, heavy metal in sediments (Mn, Zn, $\mathrm{Cd}, \mathrm{Cr}, \mathrm{Cu}, \mathrm{Pb}$ and $\mathrm{Ni}$ ) were analyzed in 14 sampling points, distributed in the upper watercourse of Subaé river, Feira de Santana-BA, in two field campaigns in order to compare dry and wet seasons. The quantification of heavy metal contents was measured by flame atomic absorption spectrometer. The heavy metal levels in the sampling points were low when compared to the global reference values for world sediments. Cadmium concentrations were always below the detection limit of the used spectrometer, and the relative abundance of the studied metals was the following: $\mathrm{Mn}>\mathrm{Zn}>\mathrm{Pb}>\mathrm{Cu}>\mathrm{Cr}>\mathrm{Ni}$. The variation range of each element concentrations was: $\mathrm{Mn} 69.3$ and $266 \mathrm{mg} \mathrm{Kg}^{-1}$; $\mathrm{Zn} 30.7$ and $426 \mathrm{mg} \mathrm{Kg}^{-1} ; \mathrm{Pb} 6.00$ and $63.6 \mathrm{mg} \mathrm{Kg}^{-1} ; \mathrm{Cu}_{4} .26$ and $66.2 \mathrm{mg} \mathrm{Kg}^{-1}$; Cr 3.24 and $52.9 \mathrm{mg} \mathrm{Kg}^{-1}$; Ni 1.96 and $24.7 \mathrm{mg} \mathrm{Kg}^{-1}$. These results are indicating low contamination risk to biota, despite of the fact that some points presented moderate risk of toxicity. The Igeo ranged from unpolluted ( $\mathrm{Zn}, \mathrm{Mn}$, $\mathrm{Cr}$, and $\mathrm{Ni}$ ) to slightly polluted $(\mathrm{Pb}$ and $\mathrm{Cu})$ in the assessed sediments. The different approaches to geochemical information treatment allow a wide and coherent debate about the environmental risk of heavy metals from anthropogenic diffuse sources.
\end{abstract}

Keywords: Igeo; heavy metals, sediments

\section{INTRODUCTION}

The increasing urban development brings, besides the benefits, the emergence of ecological problems. According to Oliveira (2010), the unbridled rise of industrialization and irregular urban occupation cause changes in terrestrial and marine ecosystems, due to the discharge of undesirable compounds in the environment. This originates a degradation scenario, causing negative impacts that probably enhance community health at risk. The presence of higher levels of several pollutants with different physical-chemical characteristics had already being proved to cause serious environmental problems (Costa et. al., 2008).
Considering this problem, environmental studies are required to determine contaminants in the environment. As sediment plays an important role in aquatic ecosystems, due to its capacity of accumulating and remobilizing polluting substances, like heavy metals, many studies have used sediments as indicators of contamination in these environments. Sediment chemical analysis can be the interpretation key of the events that occur over time in the waterbody (Esteves, 1998; Ribeiro, 2002).

The literature shows some discrepancies among researchers in relation to the acceptable concentrations in the sediment and soil compartments. There is not a common consensus about the acceptable maximum limits, since this is information 
orignated from different lithological environments. Therefore, sometimes a chemical element concentration found in an area may be considered natural for an environment and for another could be considered high, showing that it is very important to consider its location characteristics (Matschullat et al., 2000).

To reduce those problems, indexes were created as analysis parameters, in which it is considered the chemical element concentrations in the shale (sedimentary rock) and the contents found in surface sediments. Some indexes stand out as analysis parameter when related to chemical element contents in sediments, for example: Enrichment Factor (EF), Contamination Factor (CF), and Geoaccumulation Index (Igeo) (Aprile \& Bouvy, 2008; Mortatti et al., 2012).

The main objectives of this research are; (1) determinate the heavy metals distribution in sediments from the upper course of Subaé River, to assess the impact of the industrial and urban activities in this environment; (2) evaluate the status of heavy metals contamination using of different types of indexes.

\section{MATERIALS AND METHODS}

Sampling points were selected by the systemic analysis and using georeferencing techniques. The same sampling points were used in the water quality monitoring study developed by the research group where this project is inserted. Points with proximity of anthropogenic activities and accessibility were considered.

\section{Study area}

The Hydrographic Basin of the Subaé River is located in the Reconcavo North of Bahia State, covering an area of 655 $\mathrm{Km}^{2}$. The main watercourse of this basin, the Subae River, has its source in the urban perimeter of Feira de Santana city and during many years has been affected by untreated wastewater originated from enterprises installed along the river course. The degradation condition is visible from its source and it worsens all the way through the watercourse (Vilas Boas, 2006).

The geological formation of the municipality is characterized by the presence of a plateau formed by very porous and permeable sand-clay sediments responsible for the accumulation and transmission of subterranean water, creating sources and lagoons that lay on the crystalline basement (Lima, 2009).

The sampling points were located in the upper watercourse of the Hydrographic Basin of the Subae River, in the limits of the municipality of Feira de Santana - BA. The three sampling areas are represented in figure 1, which correspond to Subaé lagoons to the north and south of BR 324 (LSU), Salgada lagoon (LSA) and the source located in Pedro Suzart Avenue (NPS).

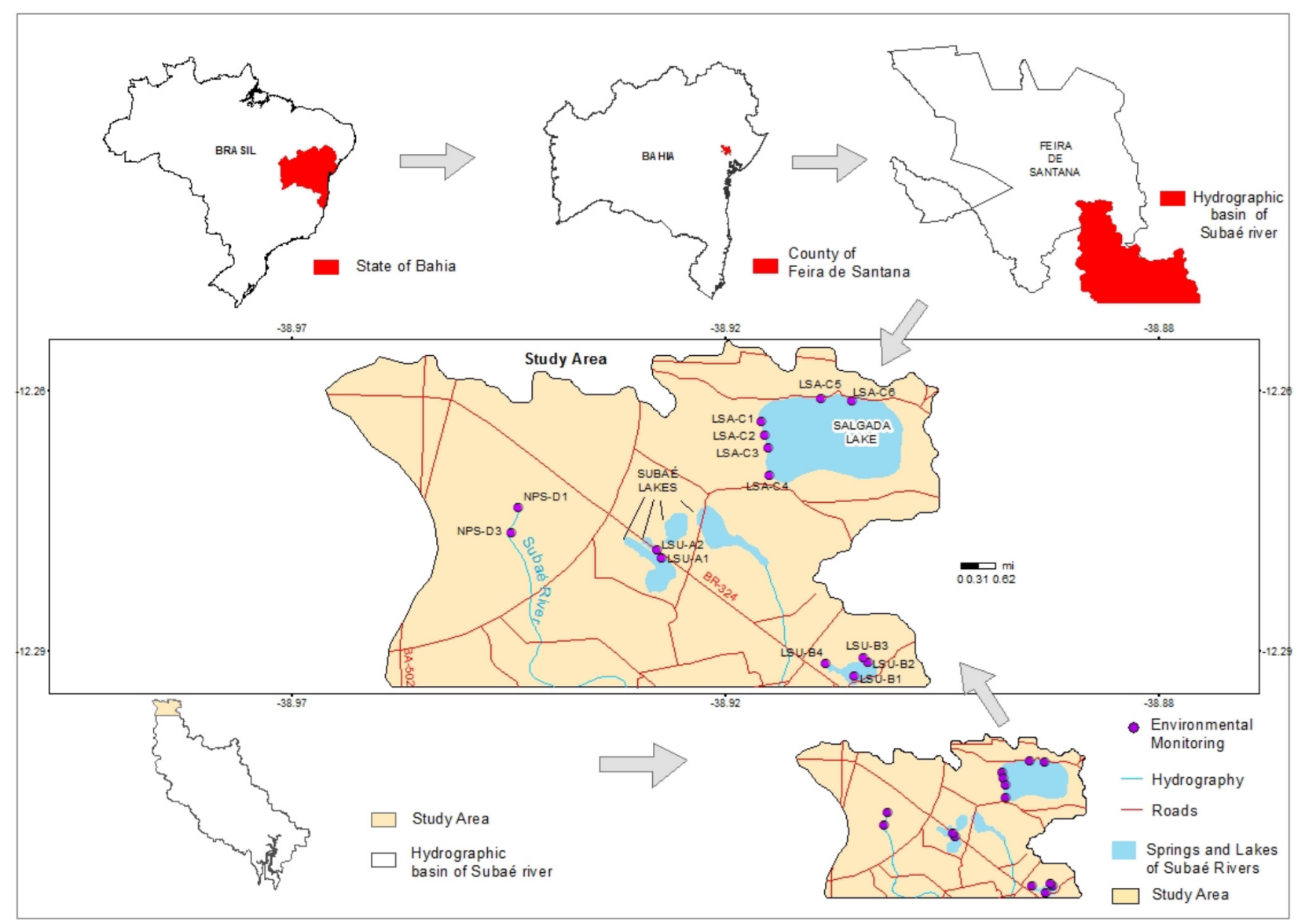

Figure 1. Localization map of Subaé River sources, Feira de Santana - Bahia. Source: Adorno, 2013. 
According to Franca-Rocha (1998) apud Cruz (2013), the sources of Subaé River are confined aquifer type, with the exception of NPS source, that was identified by remote sensing as a source without initial water accumulation and with permanent flow.

\section{Sampling}

Two field campaigns were performed for sediment sampling, the first was in May 2011 and the second, in May 2012, in order to compare the wet and dry seasons. The 14 sediment samples, with around $250 \mathrm{~g}$, were collected using a plastic shovel. The samples were identified and cold stored in a refrigerator of the Environmental Geochemistry lab (PPGM-UEFS).

\section{Sample preparation}

The samples were dried for 12 hours at $60^{\circ} \mathrm{C}$ and then ground and sieved in a 63 mesh stainless steel sieve, respectively. After sieving, approximately $1 \mathrm{~g}$ from each sediment sample was weighed in a digital scale (precision $0.0001)$.

The sediment digestion from the first field campaign was performed in an Anton Paar microwave oven, model Multiwave 3000. The samples were analyzed in analytical triplicates, placed in a Teflon vase, adding $9 \mathrm{~mL}$ of $\mathrm{HCL}$ and $3 \mathrm{~mL}$ of $\mathrm{HNO}_{3}$, and then heating to approximately $190^{\circ} \mathrm{C}$ for 30 minutes.

After digestion, each sample was filtered and filled up to $50 \mathrm{~mL}$ with ultra pure water in a volumetric flask.

\section{Analytical procedures}

The metals were quantified by flame atomic absorption spectrophotometer (FAAS), Varian brand (Model: HG- 3000). The heavy metals quantified were: $\mathrm{Cd}, \mathrm{Cr}, \mathrm{Cu}, \mathrm{Mn}, \mathrm{Ni}, \mathrm{Pb}$, and $\mathrm{Zn}$. Calibration curves were obtained through standards prepared with the same extractor of each fraction, to avoid possible mistakes. Table 1 shows the detection limits (DL) of the technique.

\section{Data Treatment}

Freshwater Sediment Quality Guidelines (SQGs) adopted by NOAA (mg $\mathrm{Kg}^{-1}$ ) was used as evaluation criteria to analyze the probability of deleterious effects on biota exposed to contaminants (Silvério et al., 2006), since the Brazilian environmental legislation still lacks criteria to evaluate the sediment quality.

SQGs showed in the Table 2 were based on databases of effects and non-effects levels, i.e. threshold effects level

Table 1. Detection limits of flame atomic absorption spectrophotometer.

\begin{tabular}{lccccccc}
\hline $\mathrm{Mn}$ & $\mathrm{Pb}$ & $\mathrm{Cu}$ & $\mathrm{Ni}$ & $\mathrm{Zn}$ & $\mathrm{Cr}$ & $\mathrm{Cd}$ \\
\hline $\mathrm{DL}$ & 0.002 & 0.006 & 0.002 & 0.004 & 0.008 & 0.005 & 0.009 \\
\hline DL= Detection limit
\end{tabular}

(TEL), probable effects level (PEL), and severe effects level (SEL), which are numerical guideline values of individual concentrations of inorganic (metals and nonmetals) and organic (a large number of different compounds) contaminants. These values were statistically defined based on the chemical concentration values of these contaminants in sediments associated to the results of toxicity tests with a large number of organisms (Mozeto, 2008; Saraiva, 2009).

For heavy metals pollution degree in sediment, the Geoaccumulation Index (Igeo) was determined as followed (Muller, 1979):

$$
\text { Igeo }=\log 2[\mathrm{Cn} / 1.5 \mathrm{Cb}]
$$

Where: $\mathrm{Cn}$ is the metal concentration in sediment $(\mathrm{mg} \mathrm{Kg}$ ${ }^{1}$ ), $\mathrm{Cb}$ is the base concentration ( $\mathrm{mg} \mathrm{Kg}^{-1}$ ), in other words, the metal background value based on the average shale composition and 1.5 is a correction factor to background data variables due to lithogenic effects (Cruz, 2013).

Müller's Geoaccumulation Index (Table 3) is an assessment modeling used to analyze the sediment contamination intensity. This index establishes the relation among the metal contents found in the analyzed area and an equivalent reference value to the world average shale for metals associated with clay which allows the calculation of the contamination level of different areas (Cruz, 2013).

\section{RESULTS AND DISCUSSION}

\section{Determination of heavy metal concentrations}

Fine-grained fractions $(<63 \mu \mathrm{m})$ of surface sediments were analyzed. Table 4 and table 5 show the heavy metal concentrations found in sediments in the sampled points in the two field campaigns.

Table 2 - TEL, PEL, and SEL guidelines used by the NOAA (mg Kg-1)

\begin{tabular}{|c|c|c|c|c|c|c|c|}
\hline Effect level & $\mathrm{Cd}$ & $\mathrm{Cr}$ & $\mathrm{Cu}$ & $\mathrm{Mn}$ & $\mathrm{Ni}$ & $\mathrm{Pb}$ & $\mathrm{Zn}$ \\
\hline TEL & 1 & 37 & 36 & - & 18 & 35 & 123 \\
\hline PEL & 4 & 90 & 197 & - & 36 & 91 & 315 \\
\hline SEL & 10 & 110 & 110 & 1100 & 75 & 250 & 820 \\
\hline
\end{tabular}

PEL (probable effects level): sediment contamination level that can be tolerated by most of the organisms.

SEL (severe effect levels): level in which can be expected disturbances in the sediment-dwelling communities.

Table 3. Intensity scale of the Geoaccumulation index

\begin{tabular}{lcc}
\hline Pollution intensity & Accumulation in soil (Igeo) & Igeo class \\
\hline Very heavily polluted & $>5$ & 6 \\
Heavily to very heavily polluted & $4-5$ & 5 \\
Heavily polluted & $3-4$ & 4 \\
Moderated to heavily polluted & $2-3$ & 3 \\
Moderately polluted & $1-2$ & 2 \\
Slightly to moderately polluted & $0-1$ & 1 \\
Practically unpolluted & $<0$ & 0 \\
\hline
\end{tabular}


Cadmium concentration, from all analyzed sediments, were always below the detection limit of the equipment $\left(0.0009 \mathrm{mg} \mathrm{Kg}^{-1}\right)$. Metal abundance in a descending order was: $\mathrm{Mn}>\mathrm{Zn}>\mathrm{Pb}>\mathrm{Cu}>\mathrm{Cr}>$ Ni. Manganese was the more abundant element in surface sediments from the analyzed ones. Probably because $\mathrm{Mn}$ is trapped in the solid phase of the sediment, compounding the group of majority elements $(\mathrm{Fe}, \mathrm{Al}, \mathrm{Ca}, \mathrm{Mn})$. It is also considered good geochemical support due to its capacity to scavenge others heavy metals by mechanisms like precipitation and adsorption, mainly in oxides and hydroxides forms (Forstner \& Wittmann, 1981; Wetzel, 1983; Esteves, 1998).

Mn concentrations ranged from 69.33 to $266.09 \mathrm{mg} \mathrm{Kg}^{-1}$ (Table 4). There was an increase of Mn concentration in seven of the fourteen points sampled in the second field campaign.
Despite Mn contamination in aquatic ecosystems has different anthropic sources, environments with higher concentrations are areas affected by urbanization and disordered occupation (LSU A1). Probably, domestic sewage wastes are sources of Mn to those environments.

Zn concentrations ranged from 30.73 to $426.00 \mathrm{mg} \mathrm{Kg}^{-1}$ (Table 4). There was an increase in $\mathrm{Zn}$ concentration in the second field campaign in twelve of the fourteen sampled points; there was a reduction only in the NPS D1 and NPS D3 points, which showed higher concentrations in the first field campaign. The increase of $\mathrm{Zn}$ mobility (sediment-water) occurred in conditions of high oxidation and in acid medium (Reimann \& Caritat, 1998).

The increase of $\mathrm{Zn}$ concentrations present in most of the points is probably indicating anthropogenic contribution.

Table 4. Average, and standard deviation, heavy metal levels $\left(\mathrm{mg} \mathrm{Kg}^{-1}\right)$ in surface sediments from Subaé River, first field campaign (May 2011).

\begin{tabular}{lcccccc}
\hline & $\mathrm{Mn}$ & $\mathrm{Pb}$ & $\mathrm{Cu}$ & $\mathrm{Ni}$ & $\mathrm{Zn}$ & $\mathrm{Cr}$ \\
\hline LSAC1 & $70.87 \pm 3.1$ & $34.81 \pm 1.9$ & $39.97 \pm 1.3$ & $20.62 \pm 1.5$ & $49.20 \pm 2.9$ & $28.92 \pm 3.8$ \\
LSA C2 & $93.58 \pm 1.7$ & $35.98 \pm 1.9$ & $28.26 \pm 1.0$ & $14.54 \pm 0.6$ & $30.73 \pm 2.5$ & $16.39 \pm 0.9$ \\
LSA C3 & $69.33 \pm 3.1$ & $44 \pm 2.0$ & $31.73 \pm 2.0$ & $18.8 \pm 0.4$ & $56 \pm 5.3$ & $27.13 \pm 1.3$ \\
LSA C4 & $107.67 \pm 2.0$ & $41.61 \pm 0.3$ & $33.77 \pm 3.0$ & $24.50 \pm 0.4$ & $50.88 \pm 4.5$ & $29.06 \pm 1.1$ \\
LSA C5 & $105.81 \pm 7.4$ & $21.57 \pm 2.0$ & $<0.002$ & $2.61 \pm 1.1$ & $<0.008$ & $3.24 \pm 1.5$ \\
LSA C6 & $100.94 \pm 6.7$ & $38.83 \pm 0.2$ & $35.37 \pm 1.1$ & $14.70 \pm 2.9$ & $94.41 \pm 6.3$ & $14.63 \pm 1.3$ \\
LSU A1 & $200.58 \pm 6.2$ & $25.61 \pm 3.1$ & $66.24 \pm 0.04$ & $12.74 \pm 1.3$ & $105.59 \pm 3.4$ & $19.29 \pm 6.1$ \\
LSU A2 & $175.56 \pm 5.6$ & $34.05 \pm 2.1$ & $25.84 \pm 0.7$ & $24.70 \pm 1.1$ & $71.44 \pm 6.3$ & $52.87 \pm 2.3$ \\
LSU B1 & $144.47 \pm 3.3$ & $33.96 \pm 0.2$ & $4.26 \pm 0.1$ & $13.32 \pm 1.1$ & $45.96 \pm 4.3$ & $19.78 \pm 2.3$ \\
LSU B2 & $115.58 \pm 5.8$ & $21.95 \pm 2.1$ & $20.75 \pm 0.9$ & $11.04 \pm 1.4$ & $64.52 \pm 9.7$ & $15.37 \pm 2.3$ \\
LSU B3 & $96.60 \pm 7.4$ & $16.47 \pm 2.5$ & $15.22 \pm 4.7$ & $1.99 \pm 0.3$ & $42.81 \pm 8.4$ & $<0.005$ \\
LSU B4 & $124.6 \pm 8.1$ & $24 \pm 3.5$ & $11.13 \pm 1.9$ & $3.73 \pm 1.9$ & $42 \pm 8.1$ & $<0.005$ \\
NPS D1 & $123.9 \pm 7.2$ & $34.72 \pm 0.6$ & $54.36 \pm 8.5$ & $7.73 \pm 1.9$ & $426.85 \pm 14.0$ & $<0.005$ \\
NPS D3 & $113.02 \pm 3.3$ & $63.57 \pm 1.3$ & $56.32 \pm 2.4$ & $12.60 \pm 1.1$ & $408 \pm 11.3$ & $<0.005$ \\
\hline
\end{tabular}

Table 5. Average, and standard deviation, heavy metal levels ( $\left.\mathrm{mg} \mathrm{Kg}^{-1}\right)$ in surface sediments from Subaé River, second field campaign (May 2012).

\begin{tabular}{lcccccc}
\hline & $\mathrm{Mn}$ & $\mathrm{Pb}$ & $\mathrm{Cu}$ & $\mathrm{Ni}$ & $\mathrm{Zn}$ & $\mathrm{Cr}$ \\
\hline LSA C1 & $119.3 \pm 2.54$ & $28.00 \pm 0.11$ & $44.94 \pm 3.89$ & $12.67 \pm 1.20$ & $53.03 \pm 10.2$ & $9.88 \pm 1.52$ \\
LSA C2 & $95.16 \pm 6.26$ & $27.27 \pm 2.47$ & $42.53 \pm 9.43$ & $9.97 \pm 1.96$ & $116.2 \pm 37.6$ & $5.50 \pm 1.59$ \\
LSA C3 & $79.40 \pm 6.87$ & $32.50 \pm 1.88$ & $25.93 \pm 3.86$ & $7.80 \pm 0.15$ & $59.14 \pm 3.15$ & $17.19 \pm 2.41$ \\
LSA C4 & $266.1 \pm 9.62$ & $32.01 \pm 2.20$ & $33.47 \pm 0.69$ & $15.34 \pm 1.21$ & $69.13 \pm 0.83$ & $35.19 \pm 5.73$ \\
LSA C5 & $122.0 \pm 12.74$ & $33.39 \pm 2.50$ & $33.12 \pm 4.03$ & $7.85 \pm 2.71$ & $114.9 \pm 17.2$ & $37.94 \pm 29.35$ \\
LSA C6 & $127.47 \pm 9.59$ & $33.26 \pm 2.52$ & $26.50 \pm 5.59$ & $5.32 \pm 1.13$ & $96.4 \pm 8.52$ & $5.46 \pm 1.47$ \\
LSU A1 & $160.7 \pm 8.93$ & $37.54 \pm 3.24$ & $63.35 \pm 3.20$ & $7.24 \pm 1.10$ & $133.1 \pm 2.79$ & $16.23 \pm 1.17$ \\
LSUA2 & $146.7 \pm 13.98$ & $33.00 \pm 1.60$ & $35.42 \pm 6.99$ & $8.0 \pm 0.05$ & $105.1 \pm 24.6$ & $7.70 \pm 1.60$ \\
LSU B1 & $130.3 \pm 7.25$ & $26.03 \pm 3.94$ & $14.15 \pm 1.16$ & $4.00 \pm 1.99$ & $50.73 \pm 1.14$ & $13.19 \pm 9.24$ \\
LSU B2 & $89.1 \pm 8.03$ & $6 \pm 5.66$ & $21.15 \pm 6.28$ & $4.02 \pm 2.02$ & $89.37 \pm 4.77$ & $<0.005$ \\
LSU B3 & $96.21 \pm 3.94$ & $30.56 \pm 3.86$ & $28.01 \pm 4.29$ & $5.97 \pm 1.94$ & $77.8 \pm 10.19$ & $14.20 \pm 4.71$ \\
LSU B4 & $118.44 \pm 9.61$ & $19.31 \pm 1.15$ & $24.06 \pm 16.33$ & $5.99 \pm 0.06$ & $47.70 \pm 2.41$ & $2.22 \pm 3.84$ \\
NPS D1 & $135.77 \pm 8.81$ & $46.78 \pm 6.02$ & $45.65 \pm 5.80$ & $5.86 \pm 0.14$ & $148.3 \pm 15.2$ & $14.27 \pm 4.21$ \\
NPS D3 & $108.14 \pm 10.9$ & $27.51 \pm 0.23$ & $16.65 \pm 1.57$ & $1.96 \pm 0.02$ & $64.25 \pm 8.6$ & $<0.005$ \\
\hline
\end{tabular}


Since $\mathrm{Zn}$ is present in some common daily use products like deodorants and shampoos and these became domestic sewage components, and then when these wastes are discharged untreated, contribute to metal concentration increase (Boyd \& Massaut, 1999).

Ni concentrations ranged from 1.96 to $24.70 \mathrm{mg} \mathrm{Kg}{ }^{-1}$ (Table 4). There was an increase in Ni concentration in three of the fourteen points analyzed in the second field campaign. According to Trindade (2012), the presence of $\mathrm{Zn}$ in high concentrations may inhibit the $\mathrm{Ni}$ adsorption in sediments, due to competitive adsorption. That would explain the low $\mathrm{Ni}$ concentrations found in sediments, mainly in points where the higher $\mathrm{Zn}$ values in the sediment were detected.

The study areas probably suffer influence from one or more activities in which $\mathrm{Ni}$ is included. But since several activities around the study areas can be influencing the presence of $\mathrm{Ni}$, there is no a specific area that are exposed in a more intensive way.

$\mathrm{Cu}$ concentrations ranged from 4.26 to $66.24 \mathrm{mg} \mathrm{Kg}^{-1}$ (Table 4). There was an increase in $\mathrm{Cu}$ concentration in nine of the fourteen points analyzed in the second field campaign. According to Pedrozo \& Lima (2001), one of the $\mathrm{Cu}$ anthropogenic sources are human and animal sewage that can be one of the causes for the presence of $\mathrm{Cu}$ in that point.

$\mathrm{Pb}$ concentrations ranged from 6.00 to $63.57 \mathrm{mg} \mathrm{Kg}^{-1}$ (Table 4 and 5). There was an increase in $\mathrm{Pb}$ concentration in four of the fourteen points analyzed. The increase in $\mathrm{Pb}$ concentration may originate from an enrichment source like domestic sewage. According to Paoliello \& Chasin (2001), domestic waste is one of $\mathrm{Pb}$ emission sources, along with superficial and urban drainage and atmospheric deposition are significant indirect $\mathrm{Pb}$ sources found in aquatic environments.

High concentrations of this element in other sampling points of the river source area indicate two possibilities, the area is naturally enriched by that metal, or the $\mathrm{Pb}$ emission sources next to the river sources analyzed affect as a whole. Contamination by $\mathrm{Pb}$ is irreversible, which generates an accumulative process, even when small amounts are added to the environment (Paoliello \& Chasin, 2001). Cr concentrations ranged from 3.24 to $52.87 \mathrm{mg} \mathrm{Kg}^{-1}$ (Table 4 and 5). There was an increase in five of the fourteen points analyzed in the second field campaign.

Poleto (2007) and Mortatti et al. (2012) highlight that river stretches that flow through urban areas have a greater potential polluter of the sediment, due to the additional presence of pollutants from untreated sewage releases and intense vehicular traffic. Lacerda (1997) mention that high contents of organic matter and low oxygenation seem to be the factors that control the metal accumulation in the sediment, because it alters the adsorption capacity and maintain the sediment in reduced state.

In urban areas, the vehicle flow in impermeable areas tends to concentrate the metals that must be transported by the drainage system during the rain events, polluting the nearby waterbodies through the surface drainage, one of the primary sources of sediment contamination. Those factors in conjunction create an increase in metal concentration in the sampled points (Dias, 1999).

\section{Sediment quality}

$\mathrm{Cu}$ when compared to the Sediment Quality Guidelines (TEL, PEL, and SEL) in the first campaign showed concentrations below the TEL limits, with the exception of LSA C1, LSU A1, NPS D1, and NPS D3, which surpassed the limits, but remaining below the PEL. In the second campaign, the point corresponding to LSA C2 remained above the TEL limit and there was a metal concentration decreasing in point NPS D3, remaining below the TEL. According to evaluation criteria, the chance that $\mathrm{Cu}$ values cause some effects on biota is low (Figure 2).

$\mathrm{Cu}$ is an essential element and required in low concentrations for all biota. Concentrations above the tolerated level cause harmful effects which can be sub-lethal (changes in biochemical and physiological functions) and lethal (damages reach high proportions and cause risk of death) (Rand, 1995; Oliveira, 2003).

$\mathrm{Cr}$ values in the two field campaigns were below the TEL limit for all the points, except the point LSU A2 which exceeded the TEL limit but remained below the PEL limit. The probability of $\mathrm{Cr}$ values cause deleterious effects to the biota would be low according to the evaluation criteria (Figure 3).

$\mathrm{Cr}$ (III) is an essential element for animals and humans and, despite the presence in all the plants, there is no evidence that it is essential to them. However, Cr (VI), besides not being essential, is more toxic, even in low concentrations. Exposition effects to high $\mathrm{Cr}$ levels include decrease of organism body size and growth rate, and also influence the reproduction and offspring survival rate in aquatic organisms (Masutti, 2004).

Mn concentrations presented well below the SEL recommended limit, there is no TEL and PEL reference values for this element. Although its concentrations are relatively high if compared to the concentrations found for the other

\section{$\mathrm{Cu}$}

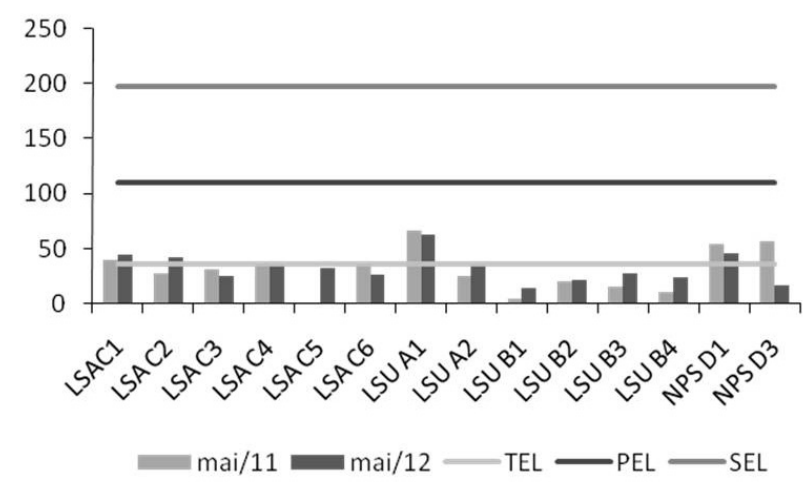

Figure 2. $\mathrm{Cu}$ concentrations compared to the guideline values of NUAA (mg $\left.\mathrm{Kg}^{-1}\right)$. 
analyzed metals, those values cannot be directly related to a possible concentration able to causing deleterious effects, mainly, related to toxicity to biota. Since manganese is one of the most abundant elements in the Earth's crust, it is normal to encounter high concentrations in sediments (Figure 4).

Most of the sampled points presented Ni concentration values within the TEL limits. According to the evaluation criteria, the chances that the $\mathrm{Ni}$ concentrations found cause any effects on biota is low, but monitoring those areas is necessary because $\mathrm{Ni}$, despite of being an essential metal, in high concentrations can cause heart and other tissue degeneration and be also be carcinogenic in animals (Figure 5) (Favaro et al., 2007).

$\mathrm{Pb}$ concentrations presented values above TEL for the points LSA C3, LSA C4, LSA C6, LSU A1, NPS D1, and NPS D3. There was an increasing concentration of $\mathrm{Pb}$ in four points in the second field campaign. According to the evaluation criteria, the chance that the $\mathrm{Pb}$ values found cause any effects on biota would be minimum, but based on $\mathrm{Pb}$ concentrations obtained in the points NPS D3 and NPS D1,

\section{$\mathrm{Cr}$}

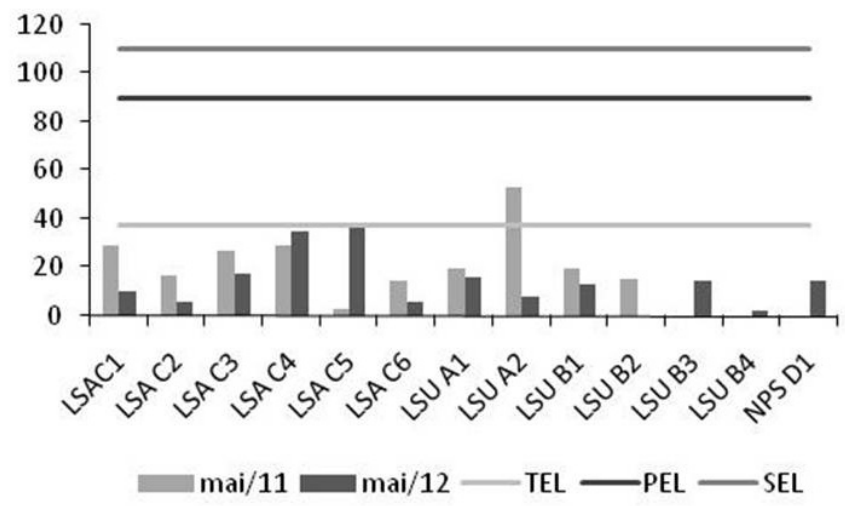

Figure 3. Cr concentrations compared to the guideline of NOAA $\left(\mathrm{mg} \mathrm{Kg}^{-1}\right)$.

\section{Mn}

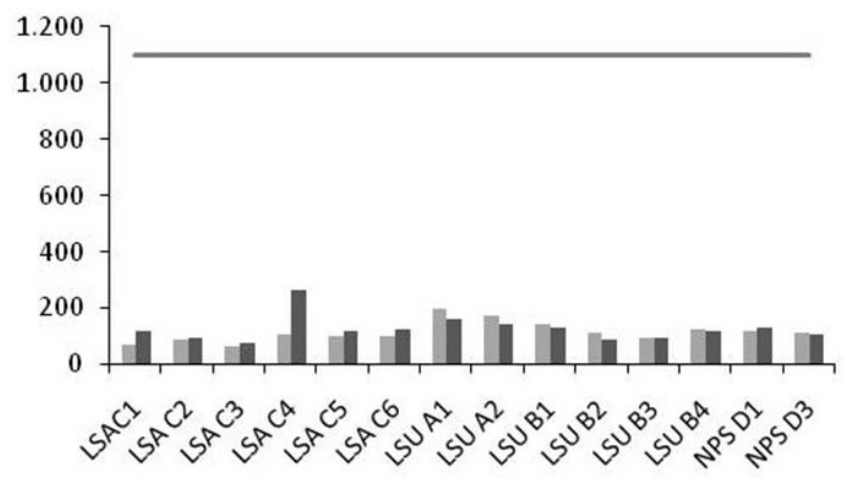

an upward trend can be observed in the concentration of this metal mainly in the Pedro Suzart source (Figure 6).

$\mathrm{Pb}$ is a nonessential toxic element which accumulates in the organism and practically affects all organs and systems, and also, an important aspect of the toxic effects of $\mathrm{Pb}$ is the reversibility of the induced biochemical and functional modifications. Knowing the toxic power of $\mathrm{Pb}$, this area must be monitored with the aim to mapping this metal concentration and distribution in time and space.

Zn presented higher concentrations than PEL limit in two points of the first field campaign (NPS D1 and NPS D3), and there was a reduction of those concentrations in the second field campaign. This fact may be related to the pavement and drainage works developed in that place at the moment of the second field campaign, which stirred up the sediment of the place, bringing up deeper sediment layers. According to the evaluation criteria, concentrations with values above PEL may cause moderated risks to the biota (Figure 7).

$\mathrm{Zn}$ is an essential element for the metabolism of most organisms, however, when plants and animals are exposed to concentrations considered toxic, the normal growth and metabolism of plant species can be affected.

According to Poleto (2007) the contaminated bottom sediments in lake represent risk to the aquatic ecosystem,

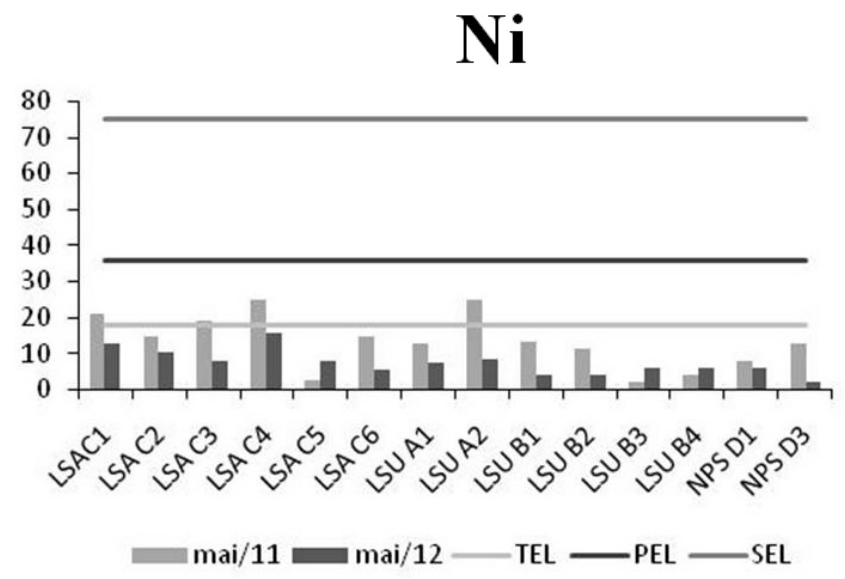

Figure 5. Ni concentrations compared to the guidelines of NOAA $\left(\mathrm{mg} \mathrm{Kg}^{-1}\right)$.

\section{$\mathbf{Z n}$}

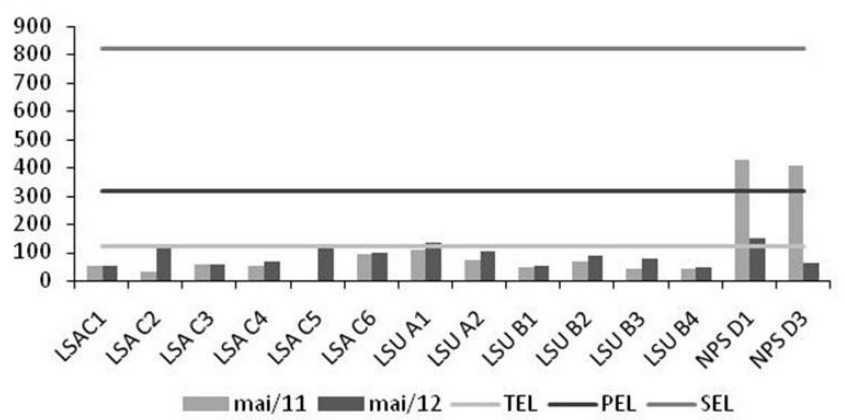

Figure 6. $\mathrm{Pb}$ concentrations compared to the guidelines of NOAA $\left(\mathrm{mg} \mathrm{Kg}^{-1}\right)$. 


\section{$\mathbf{P b}$}

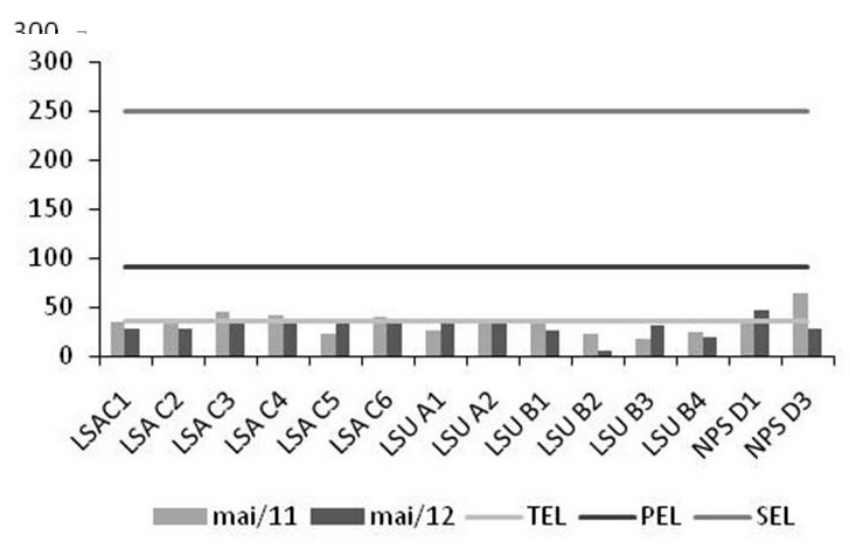

Figure 7. $\mathrm{Zn}$ concentrations compared to the guidelines of NOAA $\left(\mathrm{mg} \mathrm{Kg}^{-1}\right)$.

because it is used as habitat for benthic and epibenthic organisms, directly affecting them and indirectly affecting non-aquatic consumers (humans and all wild organisms).

Risks to biota can be inferred as low when considering the criteria used as parameter to establish if heavy metal concentrations found in sediments of Subaé river sources are harmful. But, these values cannot predict the dynamic of the pollutants associated to sediments within aquatic ecosystems, neither the possible effects that the variations of concentration within the established limits may cause, in other words, the concentrations near to lower limits will produce different effects compared to concentrations near to upper limits.

Establishing permanent monitoring plans is necessary in order to verify responses of the biota to the presence of those elements. Also, the continuous study in this area is necessary to the contaminant levels do not increase over the years and damage the biota and all the aquatic system.

\section{Geoaccumulation index}

The pollution categories of surface sediments of Subaé River sources were determined by the Geoaccumulation index calculation. The Geoaccumulation Index (Igeo) of the metals $\mathrm{Cr}, \mathrm{Cu}, \mathrm{Mn}, \mathrm{Ni}, \mathrm{Pb}, \mathrm{Zn}$ found in the surface sediment of the two field campaign are presented in table 6 .

$\mathrm{Cu}$ was not detected in point LSA $\mathrm{C} 5$ and $\mathrm{Cr}$ was not detected in points LSU B3 and B4 and in the points corresponding to Pedro Suzart source (NPS D1 and D3), in the first field campaign and in the second field campaign, Cr was not detected in points LSU B2 and NPS D3 and, therefore, there are no categories determined for those points. The values indicate that the quantified $\mathrm{Pb}$ and $\mathrm{Cu}$ contents, in the two field campaigns, in most of the points fit into the Igeo 1 category (values between 0 and 1 ) which corresponds to a slightly to moderately polluted sediment. For $\mathrm{Zn}$, the points corresponding to Pedro Suzart source in the first field campaign were in the Igeo 1 category, but with the improvement in the sewage system and the works developed in the place, the Geoaccumulation Index in those points moved to the category Igeo 0. All values found for $\mathrm{Mn}, \mathrm{Ni}$, and $\mathrm{Cr}$ in the two field campaigns are in the category Igeo 0 .

Concerning Igeo, the Subaé River sources are slightly to moderately polluted by $\mathrm{Cu}$ and $\mathrm{Pb}$. These data serve as a warning to these points do not become heavily polluted, causing environmental damages to the study area and to the entire Subaé river watercourse.

Table 6. Metal Geoaccumulation index of the surface sediment of Subaé River sources, Feira de Santana- BA.

\begin{tabular}{|c|c|c|c|c|c|c|c|c|c|c|c|c|}
\hline & \multicolumn{2}{|c|}{$\mathrm{Mn}$} & \multicolumn{2}{|c|}{$\mathrm{Pb}$} & \multicolumn{2}{|c|}{$\mathrm{Cu}$} & \multicolumn{2}{|c|}{$\mathrm{Ni}$} & \multicolumn{2}{|c|}{$\mathrm{Zn}$} & \multicolumn{2}{|c|}{$\mathrm{Cr}$} \\
\hline & may/11 & may/12 & may/11 & may/12 & may/11 & may/12 & may/11 & may/12 & may/11 & may/12 & may/11 & may/12 \\
\hline LSA C1 & 0 & 0 & 1 & 1 & 1 & 1 & 0 & 0 & 0 & 0 & 0 & 0 \\
\hline LSA C2 & 0 & 0 & 1 & 1 & 1 & 1 & 0 & 0 & 0 & 0 & 0 & 0 \\
\hline$\overline{\mathrm{LSA} C 3}$ & 0 & 0 & 1 & 1 & 1 & 1 & 0 & 0 & 0 & 0 & 0 & 0 \\
\hline LSA C4 & 0 & 0 & 1 & 1 & 1 & 1 & 0 & 0 & 0 & 0 & 0 & 0 \\
\hline LSA C5 & 0 & 0 & 1 & 1 & & 1 & 0 & 0 & 0 & 0 & 0 & 0 \\
\hline LSA C6 & 0 & 0 & 1 & 1 & 1 & 1 & 0 & 0 & 0 & 0 & 0 & 0 \\
\hline LSU A1 & 0 & 0 & 1 & 1 & 1 & 1 & 0 & 0 & 0 & 0 & 0 & 0 \\
\hline LSU A2 & 0 & 0 & 1 & 1 & 1 & 1 & 0 & 0 & 0 & 0 & 0 & 0 \\
\hline LSU B1 & 0 & 0 & 1 & 1 & 0 & 1 & 0 & 0 & 0 & 0 & 0 & 0 \\
\hline LSU B2 & 0 & 0 & 1 & 1 & 1 & 1 & 0 & 0 & 0 & 0 & 0 & \\
\hline LSU B3 & 0 & 0 & 1 & 1 & 1 & 1 & 0 & 0 & 0 & 0 & & 0 \\
\hline LSU B4 & 0 & 0 & 1 & 1 & 1 & 1 & 0 & 0 & 0 & 0 & & 0 \\
\hline NPS D1 & 0 & 0 & 1 & 1 & 1 & 1 & 0 & 0 & 1 & 0 & & 0 \\
\hline NPS D3 & 0 & 0 & 1 & 1 & 1 & 1 & 0 & 0 & 1 & 0 & & \\
\hline
\end{tabular}

Legend: 


\section{FINAL CONSIDERATIONS}

Presence of heavy metals such as $\mathrm{Cr}, \mathrm{Zn}, \mathrm{Mn}, \mathrm{Ni}, \mathrm{Cu}$, and $\mathrm{Pb}$ were observed in the sediments of the sources in all the study areas. Higher heavy metal concentrations in sediments were recorded in points where there are evidences of organic load discharge and domestic effluents, as in the case of the Subaé lagoon and the Pedro Suzart avenue source.

The results found in that research show that heavy metal levels in the sampled points are low compared to the global reference values defined for the world sediments by Muller (1979) and by the Sediment Quality Guidelines. Regarding the contamination risk to biota, it is worth mentioning that some points presented slight risk of toxicity and the harmful effects caused by the analyzed elements show the need for establish permanent monitoring plans, in order to verify the biota behavior at the presence of those elements.

The heavy metal concentrations ( $\mathrm{Cr}, \mathrm{Cu}, \mathrm{Mn}, \mathrm{Ni}, \mathrm{Pb}, \mathrm{Zn})$ present in the sediment, may be related to natural sources and the anthropogenic contributions caused mainly by the use of the water for industrial and residential waste, grounding for opening of access roads, construction of roadsides as well as the increase of the human occupation rate in the area.

Despite of the lack of vegetal coverage, combined with the excessive urbanization in the sampled areas, the sampled area did not present signals of serious contamination, but the metal contents recorded serve as a warning, because it is unknown the frequency and quantity these metals are thrown into the study area.

\section{REFERENCES}

ADÔRNO, E. V., SANTOS, E. S., JESUS, T. B. 2013. SIG e regressão linear para avaliação ambiental das nascentes do rio Subaé em Feira de Santana-BA. Bol. Goiano Geogr. (Online). Goiânia, 33 ( 2): 63-80. http://dx.doi.org/10.5216/bgg.v33i2.25557

APRILE, F. M. \& BOUVY, M. 2008. Distribution and enrichment of heavy metals in sediments at the Tapacura River basin. Brazil. Braz. J. Aq. Sci. and Tech., 12(1), 1-8. http://dx.doi. org/10.14210/bjast.v12n1.p1-8

BOYD, C. E.; MASSAUT, L. 1999. Risks associated with the use of chemicals in pond aquaculture. Aquac Eng,, v. 20, 113132p. http://dx.doi.org/10.1016/s0144-8609(99)00010-2

COSTA, M. C. R., DAMILANO, C. R., VASCONCELLOS, A., COSTA, R. C. 2008. Diagnóstico ambiental de área industrial contaminada por metais pesados. Revista Biociências, UNITAU, 14 (1): 51-61. http://periodicos.unitau.br/ojs-2.2/index.php/ biociencias/article/viewFile/476/275

CRUZ, M. A. S., SANTOS, L. T. S. O., LIMA, L. G. L. M., JESUS, T. B. 2013. Caracterização granulométrica e mineralógica dos sedimentos como suporte para análise de contaminação ambiental em nascentes do rio Subaé, Feira de Santana (BA). Geochim. Bras. , 27(1): 49-62. http://dx.doi.org/10.5327/z01029800201300010005

DIAS, M. do C. O. (Coord.). 1999. Manual de impactos ambientais: orientações básicas sobre aspectos ambientais de atividades produtivas. Embrapa Solos - INFOTECA-E. Fortaleza: Banco do Nordeste, 297 p. https://www.infoteca.cnptia.embrapa.br/ handle/doc/928622

ESTEVES, F. A. 1998. Fundamentos de Limnologia. Rio de Janeiro, INTERCIÊNCIA/FINEP, 575p.

FAVARO, D.I.T., DAMATTO, S.R. MOREIRA, E.G., MAZZILLI, B.P. CAMPAGNOLI, F. 2007. Chemical characterization and recent sedimentation rates in sediment cores from Rio Grande reservoir, SP, Brazil, J. Radioanal. Nucl. Chem., 273(2), 451463. http://dx.doi.org/10.1007/s10967-007-6855-2

FÖRSTNER, U. \& WITTMANN, G. T. W. 1981. Metal Pollution in the Aquatic Environment. Springer - Verlag, Berlim Heidelberg New York. 486 p.

FRANCA-ROCHA, W. J. S. \& NOLASCO, M. C. 1998. Projeto Nascentes: um olhar sobre Feira de Santana. Universidade Estadual de Feira de Santana, UEFS, Feira de Santana.

LACERDA, L. D. 1997. Contaminação por mercúrio no Brasil: fontes industriais vs garimpo de ouro. Quím. Nova, 20(.2): 196 199. http://dx.doi.org/10.1590/S0100-40421997000200012

LIMA. A. C. P. 2009. Avaliação da qualidade de água do aqüífero subterrâneo do entorno do Centro Industrial do Subaé- Feira de Santana- Ba. Dissertação Mestrado. Universidade Estadual de Feira de Santana, Feira de Santana, 102p. http://docplayer. com.br/6460886-Adriano-cosme-pereira-lima-avaliacao-daqualidade-da-agua-do-aquifero-subterraneo-do-entorno-docentro-industrial-do-subae-feira-de-santana-ba.html

MASSUTI, M. B. 2004. Distribuição e efeitos de cromo e cobre em ecossistemas aquáticos: Uma análise laboratorial e "in situ" (Experimentos em micro e mesocosmos). Tese de Doutorado. Universidade de São Paulo, São Carlos, 390p. http://dx.doi. org/10.11606/t.18.2004.tde-23042012-102116

MATSCHULLAT, J., OTTENSTEIN, R., REIMANN, C. 2000. Geochemical background - can we calculate it? Environ. Geol., 39(9): 990-1000.http://dx.doi.org/10.1007/s002549900084

MORTATTI. J., VENDRAMINI. D., OLIVEIRA. H. 2012. Avaliação da poluição doméstica fluvial na zona urbana do município de Piracicaba (SP). Ambi-Agua, Taubaté, 7 (2): 110119. http://dx.doi.org/10.4136/ambi-agua. 846

MOZETO, A. A. 2008. Projeto Ibirité, Fase II - Confirmação de Diagnóstico Ambiental da Represa Ibirité Laboratório de Biogeoquímica Ambiental. São Carlos: Laboratório de Biogeoquímica Ambiental, UFSCar. 87 p.

MULLER. G.1979. Schwermetalle in den Sedimenten des RheinsVeãderung seit. Umschav, 79 : 133-149.

OLIVEIRA. A. 2010. Distribuição e fracionamento de cádmio, Chumbo, cromo e níquel no sedimento do Arroio Estância Velha. Monografia de Conclusão do Curso em Engenharia Industrial Química). Universidade Feevale, Nova Hamburgo, 98p.

OLIVEIRA, C. P. F. 2003. Efeito de cobre e chumbo, metais pesados presentes na água de formação derivada da extração do petróleo da província petroleira do Urucu - Am. sobre o tambaqui. Colossoma macropomum (Curvier. 1818). Dissertação de Mestrado. Universidade Federal do Amazonas, Manaus, 70p.

PAOLIELLO, M. M. B. \& CHASIN, A. A. M. 2001. Ecotoxicologia do chumbo e seus compostos. Série Caderno de Referência Ambiental, v.3. Salvador: CRA, 144p. http://docplayer.com. br/142295-Ecotoxicologia-do-chumbo-e-seus-compostos.html

PEDROZO, M.F.M. \& LIMA, I.V. 2001. Ecotoxicologia do Cobre e seus Compostos. Cadernos de referência ambiental, v. 4. Salvador: CRA, 128p. http://pesquisa.bvsalud.org/portal/ resource/pt/rep-7792

POLETO, C. 2007. Fontes potenciais e qualidade dos sedimentos fluviais em suspensão em ambiente urbano. Tese de Doutorado. Universidade Federal do Rio Grande do Sul, Porto Alegre, 159p. http://www.lume.ufrgs.br/handle/10183/11337

RAND, G.M. 1995. Fundamentals of aquatic toxicology: effects, 
environmental fate and risk assessment. Taylor \& Francis, Washington, 305p.

REIMANN, C. \& CARITAT, P. 1998. Chemical elements in the environment. Springer, Verlas, 398p. http://link.springer.com/bo ok/10.1007\%2F978-3-642-72016-1

RIBEIRO, A. P. 2002. Determinação de metais pesados e outros elementos de interesse em sedimentos lacustres da estação de tratamento de esgoto de Barueri, São Paulo, por ativação neutrônica. Dissertação de Mestrado. Instituto de Pesquisas Energéticas e Nucleares, São Paulo,5p.http://pelicano.ipen.br/ PosG30/TextoCompleto/Andreza\%20Portella\%20Ribeiro_M. pdf

SARAIVA, V. K. 2009. Critérios para avaliação da qualidade de sedimentos- estudo de caso: Sub-bacia do Ribeirão Espírito Santo, afluente do Rio São Francisco. Quím. Nova, 32(8): 19952002. http://dx.doi.org/10.1590/S0100-40422009000800003

SILVÉRIO, P.F.; NASCIMENTO, M.R.L.; MOZETO, A.A.A.
Valores-Guia de Qualidade de Sedimentos de Ambientes Aquáticos Continentais e Valores de Referência de Metais e Metalóides em Sedimentos. In: MOZETO, A.A; UMBUZEIRO, G.A.; JARDIM, W.F. (Eds.), Métodos de coleta, análises físicoquímicas e ensaios biológicos e ecotoxicológicos de sedimentos de água doce. São Carlos: Cubo Multimídia, p. 71-89, 2006.

TRINDADE, W. M., HORN, A. H., RIBEIRO, E. V. 2012. Concentração de metais pesados em sedimentos do rio São Francisco entre Trê Marias e Pirapora- MG: Geoquímica e classificação de risco ambiental. Geonomos, 20(1): 64-75. http:// www.igc.ufmg.br/geonomos/PDFs/20121/08_Trindade_et al.pdf

VILAS BOAS, A. 2006. Rio Subaé: Um Caso de Escola? Rev. eletrônica Mestr. Educ. Ambient., 17: 148-166. http://www. seer.furg.br/remea/article/view/3030/1752

WETZEL. R. G.; 1983. Limnology. Sauders College Publishing, Chicago, 540p. 